\title{
Assessment of Sediment Contamination by Heavy Metals in the Water of Mgoua Catchment in the Industrial Zone of Douala (Cameroon)
}

\author{
Josephine Ndjama ${ }^{1, ~}$, Raoul Gustave Nkoue Ndondo ${ }^{2}$, Gloria Takem Eyong ${ }^{1}$, \\ Eric Belmond Biram Ngon ${ }^{1}$, Alain Fouepe Takounjou ${ }^{1}$, Georges Mafany ${ }^{1}$, \\ Clarisse Mfopou Mewouo ${ }^{3}$ \\ ${ }^{1}$ Hydrological Research Centre, Institute of Geological and Mining Research, Yaounde, Cameroon \\ ${ }^{2}$ Department of Science, University of Douala, Douala, Cameroon \\ ${ }^{3}$ Laboratory of Soil, Plant, Water and Fertilizer, Institute of Agricultural Research for Development, Yaounde, Cameroon
}

Email address:

ndjama72@yahoo.fr (J. Ndjama)

${ }^{*}$ Corresponding author

\section{To cite this article:}

Josephine Ndjama, Raoul Gustave Nkoue Ndondo, Gloria Takem Eyong, Eric Belmond Biram Ngon, Alain Fouepe Takounjou, Georges Mafany, Clarisse Mfopou Mewouo. Assessment of Sediment Contamination by Heavy Metals in the Water of Mgoua Catchment in the Industrial Zone of Douala (Cameroon). Science Journal of Analytical Chemistry. Vol. 9, No. 3, 2021, pp. 58-67. doi: 10.11648/j.sjac.20210903.11

Received: May 11, 2021; Accepted: June 9, 2021; Published: July 13, 2021

\begin{abstract}
Aquatic ecosystems are increasingly affected by human activities, notably urban sewage and industrial effluent discharges, particularly in rivers. This study assesses heavy metals contamination of sediments of the Mgoua River in Douala, Cameroon. The Geoaccumulation Index (Igeo), the Contamination Factor (FC), the Sediment Pollution Index (SPI), the Enrichment Factor (EF) and the Pollution Load Index (PLI) were used to assess the contamination risk. The mean concentration of Ti, V, Cr, Co, Ni, Cu, As, Cd, Zn, Pb, U, Rb, Sr, Y, Zr, Mo, Mn, Fe, Cs and Ba in sediments was 12601.08, 111.96, 151.93, 9.47, $65.43,161.81,7.55,2.27,419.30,248.30,49.30,12.65,89.50,39.69,3017.52,5.95,313.26,39667.32,0.97$ and $243.19 \mu \mathrm{g} / 1$, respectively. Heavy metals concentrations in sediments creased in the following order: $\mathrm{U}<\mathrm{Cs}<\mathrm{Cd}<\mathrm{Mo}<\mathrm{As}<\mathrm{Co}<\mathrm{Rb}<\mathrm{Y}<$ $\mathrm{Ni}<\mathrm{Sr}<\mathrm{V}<\mathrm{Cr}<\mathrm{Cu}<\mathrm{Ba}<\mathrm{Pb}<\mathrm{Mn}<\mathrm{Zn}<\mathrm{Ti}<\mathrm{Fe}$. The Igeo, $\mathrm{CF}$ and $\mathrm{EF}$ indicate a polymetallic contamination dominated by $\mathrm{Cu}, \mathrm{Cd}$ and $\mathrm{Pb}$ being the most important in all studied sites. The value of SPI varied between 10.95 and 37.84, suggesting that the sediments are moderately to highly polluted, with PLI higher than 1 . These indices reveal that the sediments of Mgoua river catchment were polluted with most of the heavy metals. The high concentrations of some of the metals were due to anthropogenic sources particularly the discharge of untreated industrial wastes in to watercourses. This study can therefore be used as a reference to monitor the quality of sediments of the Mgoua river.
\end{abstract}

Keywords: Sediment Quality, Geoaccumulation Index (Igeo), Contamination Factor (FC), Sediment Pollution Index (SPI), Enrichment Factor (EF), Pollution Load Index (PLI)

\section{Introduction}

The significant spike in the number of industries and the high population growth rates recorded in the past decades, particularly in cities, have resulted to serious environmental problems in many industrial regions in the world, notably in developing countries [1]. Environmental pollution by toxic organic and inorganic substances has become a major concern because of their negative impact on the environmental abiotic and biotic processes. Waste products from municipalities (with large quantities of domestic waste, industries and agrochemical products) have been discharged on the ground surface and watercourses without prior treatment. Water is the main path of transport from natural inputs (such as weathering and erosion of rocks) and anthropogenic sources (including urban, industrial and agricultural activities, terrestrial runoff and sewage disposal) in to stream [2]. 
Anthropogenic activities (industrial activities, domestic waste, urbanization and land development...), contribute to polluting rivers with heavy metals, the identification and qualification of the latter in sediments is very important. Sediments are complementary and are equally vital parts of aquatic environments acting as carriers and potential sink for various pollutants. Many contaminants such as hazardous and toxic metals are accumulated in sediments, which could be extremely harmful to the aquatic environments [3]. As such, sediments serve as sensitive indicators for monitoring contaminants in aquatic environments. Assessing the presence of heavy metals in sediments can be used to understand the potential anthropogenic and industrial risks of direct waste discharges in ecosystems. Heavy metals pollution is a major problem in several developing countries including Cameroon. Although pollution in larger rivers has been relatively studied, the geochemistry and the characterization of the sediments of some small catchment areas like that of Mgoua in the Littoral region, which receives considerable quantities of waste from industries and residences has received very few studies [4].

Furthermore, the enrichment of trace metal in some of its fraction, especially in mobile fraction might emphasize the greater role of small rivers in modifying the global picture of trace metals in the aquatic environment. Therefore, the main objective of this work is to assess the level of Trace metals (Ti), Vanadium (V), Chromium (Cr), Cobalt (Co), Nickel (Ni), Copper (Cu), Arsenic (As), Cadmium (Cd), Zinc (Zn), Lead $(\mathrm{Pb})$, Uranium (U), Rubidium ( $\mathrm{Rb}$ ), Strontium ( $\mathrm{Sr}$ ), Yttium (Y), Ziconium (Zr), Molybdenum (Mo), Manganese (Mn), Iron (Fe), Cesium (Cs) and Barium (Ba), as well as the degree of metallic pollution in sediments based on the calculation of indices: Igeo, EF, FC, SPI and PLI.

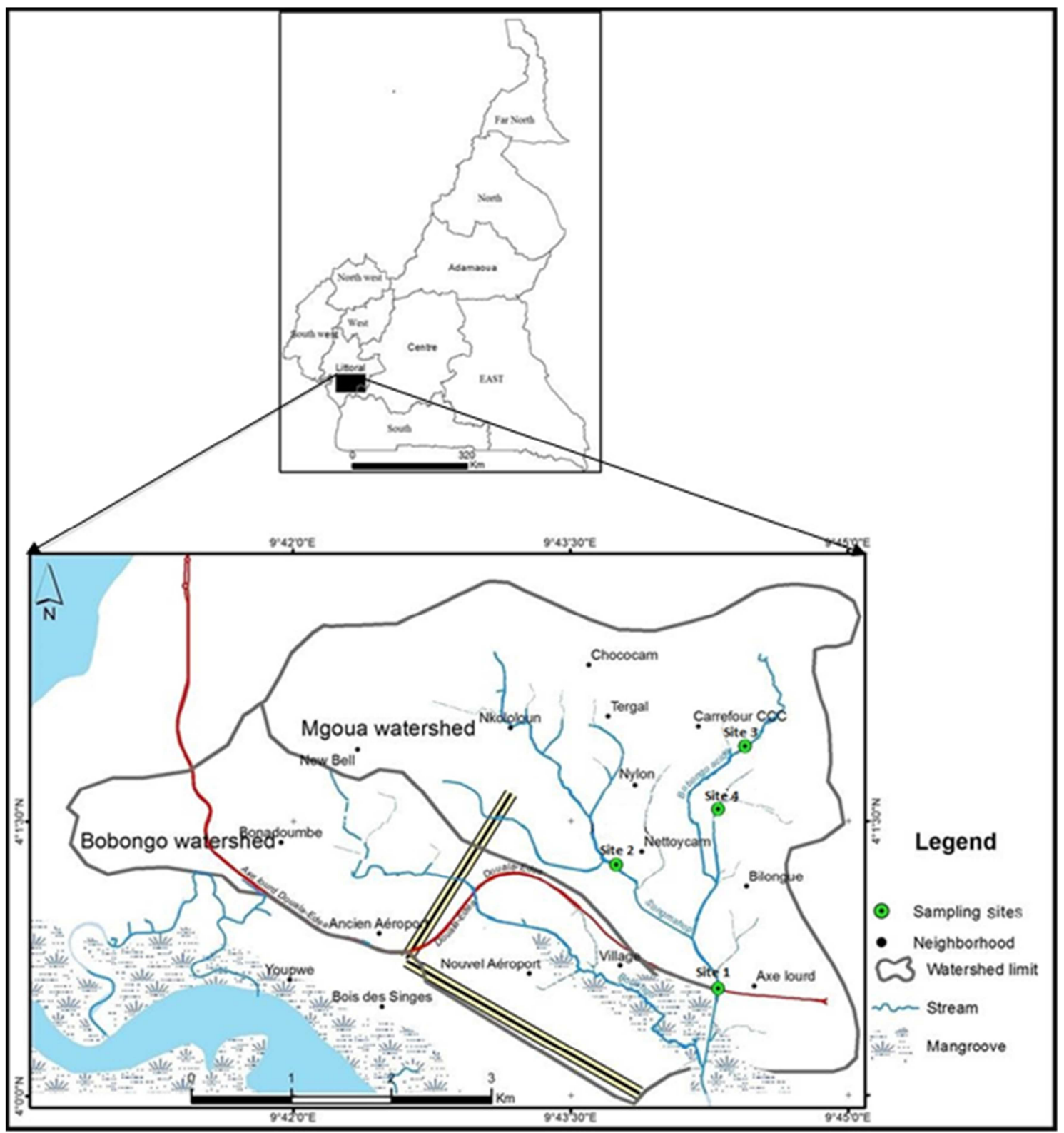

Figure 1. Map of sampling sites at Mgoua river catchment. 


\section{Materials and Methods}

The study site is located in the low land of the Littoral Region of Cameroon (Figure 1). The watershed with the main extension NE-SW covers an area of 780 ha including the Nylon, Brazzaville, Complex Chemical Cameroonian (CCC), Cameroonian Brewery Union (CBU), Cameroonian Company of Cardboard and Supply of School and Office Equipment (SOCARTO S. A). The geographical coordinates are from $4^{\circ} 00^{\prime}$ to $4^{\circ} 02^{\prime}$ latitude North and between $9^{\circ} 42^{\prime}$ and $9^{\circ} 45^{\prime}$ longitude East (Figure 1). Altitudes are no more than $100 \mathrm{~m}$. The climate is equatorial, of the Cameroonian type and under coastal influences, characterized by two (02) seasons: a long rainy season of about 9 months (from March to November) and a short dry season of about 3 months (from December to February) with an average annual rainfall of about $4000 \mathrm{~mm}$. The temperature varies between $23^{\circ} \mathrm{C}$ to $30^{\circ} \mathrm{C}$, with an average value of $27^{\circ} \mathrm{C}$ [5]. The winds are rarely violent with an average speed of $1 \mathrm{~m} / \mathrm{s}$ and the maximum speed not exceeding $14 \mathrm{~m} / \mathrm{s}$.

At the geological level, the Douala region is unconformably overlain by a sedimentary sequence ranging from Cretaceous to recent. This sequence is made up of six formations (Wouri, Matanda, Souelaba, N'Kapa, Logbaba and Mundeck) described by [6]. The study area reposes directly on the Mio-Pli-ocene to recent alluvial sediments of the basin, which constitutes the Wouri Formation. Generally, it consists of unconsolidated fine to coarse-grained sand and gravel with intercalation of silt and clay in varied proportions. The alluvium is composed predominantly of quartz and kaolinite, with a general thickness that ranges between $50-60 \mathrm{~m}$. The sedimentary series range from Albo-Aptian to Quaternary and represent a multilayer aquifer system with a sandy. These layers play an important role in the supply of water to city dwellers. There is a diversity in soils with the predominance of ferrallitic soil, the hydromorphic soils, the little evolved/moved soils and the rough mineral soils. The hydrographic network is very dense and branched out on serpentine tidal channels of varying sizes, reflecting the flatness of the region with flows which are permanently supported by a sub-flush sheet [7].

Anthropogenic activities at the community level are dominated by garages, industries (textile, mining, detergent, Artistic, steel plant, Food industry, Brewery, Cement manufacturing, soap manufacturing, Car dealer, fertilizer and pesticides manufacturing, Soap manufacturing, Metallurgy, saw-mill, Tannery, manufacturing of paints, varnishes and printing inks, plastic manufacturing, paper, battery,...), livestock and agriculture, which use water from rivers and boreholes. The Mgoua watershed receive constant discharges of untreated raw sewage and waste water from garages and other mechanical workshops could also be possible sources of heavy metals washed from the ground surface to the streams.

\subsection{Sampling and Preparation}

Sediments from four sites (site 1, site 2, site 3 and site 4) (Figure 1) for analysis were collected from the surface layer in zones with calm sedimentation having abundant fine materials and organic deposits. Sample collection was done according to the accessibility and proximity to pollutants waste discharges.

\subsection{Sample Collection and Metal Analyses}

Four samples of sediments were collected from March 2014 to February 2016. The samples were taken at a depth of 0-10 $\mathrm{cm}$ and immediately transferred into polyethylene bags. Before sampling, the polyethylene bag was washed with $10 \%$ $\mathrm{HNO}_{3}$, acid solution and rinsed with distilled water [8]. Sediments samples were transported to the laboratory using an icebox. The samples were air-dried in a dry and dust-free place at room temperature, and ground into fine powder using a pestle and a mortar before sieving in a mesh screen smaller than $63 \mu \mathrm{m}$ to get the fine fraction. After drying, sediment samples were digested with concentrated $\mathrm{NHO}_{3}$ and $\mathrm{HClO}_{4}$ acids according [9]. The digested sediment samples were analyzed with Perkin Elmer 5100ZL Inductively Coupled Plasma Mass Spectrometer (ICP-MS) to detect metal trace elements at a minimum concentration of $10-3 \mu \mathrm{g} / \mathrm{l}$, in the laboratory of the Geosciences of the Environment of Toulouse (GET, France).

\subsection{Assessment of Heavy Metals in Sediments}

Various indices were used to determine the degree of heavy metal pollution in surface sediments of the Mgoua river, Douala, Cameroon. The level of contamination from heavy metals was evaluated by determining the Igeo, CF, PLI, EF and SPI. In the interpretation of geochemical data, the choice of the background values plays a significant role. Many researchers have used the average scale values or the average crustal abundance data as reference baselines [10].

Contamination Factor $(C F)$

The (CF) was used to assess the pollution load of the sediments with respect to heavy metals. The CF is the ratio obtained by dividing the concentration of each metal in the sediment by a baseline or background value. The CF for each metal was determined by using the following formula [11]:

$$
\mathrm{CF}_{\text {metals }}=\mathrm{C}_{\text {metal }} / \mathrm{C}_{\text {background }}
$$

The CF values in Table 1 were interpreted as follows: low contamination at $\mathrm{CF}<1$; moderate contamination at $1<\mathrm{CF}<$ 3 , considerable contamination at $3<\mathrm{CF}<6$, and very high contamination at $\mathrm{CF}>6$, according to [11]. Thus, the $\mathrm{CF}$ values could enable to monitor the enrichment of a given metal in sediments over a given metal:

Table 1. Classes of Contamination Factor (CF) [11].

\begin{tabular}{lll}
\hline Class & CF & Sediment quality \\
\hline 1 & $\mathrm{CF}<1$ & Low contamination \\
2 & $1<\mathrm{CF} \leq 3$ & Moderate contamination \\
3 & $3<\mathrm{CF} \leq 6$ & Considerable contamination \\
4 & $\mathrm{CF}>6$ & Very high contamination \\
\hline
\end{tabular}

Pollution Load Index (PLI)

The PLI is used to find out the mutual pollution effect at various stations by the different elements in soils and 
sediments [12]. The PLI enable us to make an assessment of the overall toxicity status of each sampling site as well as the result of the contribution of the measured seven metals. The PLI for each site was determined as the $\mathrm{n}^{\text {th }}$ root of the multiplications of the contents, $\mathrm{CF}_{\text {metals }}$ by the following equation proposed by [13]:

$$
\mathrm{PLI}=\sqrt[n]{(\mathrm{CF} 1 \times \mathrm{CF} 2 \times \mathrm{CF} 3 \times \ldots \times \mathrm{CFn})}
$$

Where, $\mathrm{CF}$ is the contamination factor and $\mathrm{n}$ is the number of metals. The PLI value of $>1$ is polluted, whereas $<1$ indicates no pollution [13]. This index is quickly understood by unskilled staff in comparing the pollution status of different places.

\section{Geoaccumulation Index ( $\left.I_{\text {geo }}\right)$}

The $\mathrm{I}_{\text {geo }}$ has been widely used in trace metal studies since the late 1960s [14]. It has been successfully applied to the measurement of bottom sediments contamination. The $\mathrm{I}_{\text {geo }}$ enables the assessment of metal contamination in sediments by comparing current concentration with pre-industrial levels. The $I_{\text {geo }}$ was calculated using the following formula [15]:

$$
\mathrm{I}_{\mathrm{geo}}=\log _{2}\left[\mathrm{C}_{\mathrm{n}} /\left(1.5 \mathrm{~B}_{\mathrm{n}}\right)\right]
$$

Where $C_{n}$ is the measured concentration of metal $(n)$ in the sediment and $B_{n}$ represents the geochemical background of the metal $(n)$. The factor 1.5 is used for the possible variations of the background data due to lithological variations. An average shale standard for different metals reported by Rahman and Ishiga [16] was considered as the background concentration throughout the study. Legorburu [17] classified $I_{\text {geo }}$ values into seven grades or classes. The $\mathrm{I}_{\text {geo }}$ factor is not readily comparable to the other indices of metal enrichment due to the nature of the $I_{\text {geo }}$ calculation, which involves a log function and a background multiplication of 1.5 [18]. The values were interpreted as: $\mathrm{I}_{\text {geo }}>5$ extremely contaminated, $4<\mathrm{I}_{\text {geo }}<5$ heavily to extremely contaminated, $3<\mathrm{I}_{\text {geo }}<4$ heavily contaminated, $2<\mathrm{I}_{\text {geo }}<3$ moderately to heavily contaminated, $1<\mathrm{I}_{\text {geo }}<2$ moderately contaminated, $0<\mathrm{I}_{\text {geo }}<1$ uncontaminated to moderately contaminated and $\mathrm{I}_{\text {geo }}<0$ practically uncontaminated.

\section{Enrichment Factor (EF)}

$\mathrm{EF}$ is used as an index to evaluate the anthropogenic effect of heavy metals in sediments and is generally defined as the observed metal to $\mathrm{Al}$ ratio in the sample divided by the background metal/Al ratio. Generally, geochemical normalization of the heavy metals data to a conservative element such as $\mathrm{Al}$ or $\mathrm{Fe}$, whose levels are unaffected by contaminant inputs, is employed in order to identify anomalous metal concentration. The conception is that $\mathrm{Al}$ or $\mathrm{Fe}$ is a major mineral-forming element and is combined closely with fine-sized fraction of total suspended material due to its participation in aluminum silicates.

The Al concentration in the sediment samples was not measured in this study. Therefore, we used Fe rather than to calculate the EF. $\mathrm{Fe}$ is also an abundant element in the structure of clay minerals and is associated with particle surfaces as oxide coatings. Fe in estuarine sediment is mainly results from natural weathering processes and has been broadly used to normalize the metal concentrations so as to reduce particle grain size influence. Various authors have successfully used iron to normalize heavy metals contaminants [19]:

$$
\mathrm{EF}=(\mathrm{Metal} / \mathrm{Fe})_{\text {sample }} /(\mathrm{Metal} / \mathrm{Fe})_{\text {background }}
$$

Where, (Metal/Fe) sample is the ratio of concentration of heavy metal to that of iron $(\mathrm{Fe})$ in the sediment sample, and (Metal/Fe) background is the same reference ratio in the background sample. The background values of heavy metals in sediments and the background value of $\mathrm{Fe}$ were obtained from Turekian and Wedepohl [16]. The Interpretation provided by Malvandi [20] from the EF values was used for the assay. When $\mathrm{EF}<1$, it indicates that no enrichment; $<3$ is minor enrichment; $3-5$ is moderate enrichment; $5-10$ is moderately severe enrichment; $10-25$ is severe enrichment; $25-50$ is very severe enrichment; and $>50$ is extremely severe enrichment. An EF value lower than 2 suggests that heavy metals entirely originate from natural variability. It can be noted that an increase of EF values rises the anthropogenic contribution origins.

\section{Sediment Pollution Index (SPI)}

Singh et al. [21] introduced the concept of sediment pollution index (SPI). SPI is a multi-metal approach for an assessment of sediment quality with respect to trace metal concentrations along with metal toxicity. The SPI developed in this study can be expressed as:

$$
\mathrm{SPI}=\sum(\mathrm{EFm} \times \mathrm{Wm}) / \sum \mathrm{Wm}
$$

Where, EFm concentration $(\mathrm{Cn})$ is a ratio between the measured metal and the reconstructed background metal concentration (CR) instead of the average metal concentration in shale. Wm stands for toxicity weight. Toxicity weight 1 was assigned for $\mathrm{Cr}$ and $\mathrm{Zn}, 2$ for $\mathrm{Cu}$ and $\mathrm{Ni}$, and 5 for $\mathrm{Pb}$ [21]. The following classification is given for the SPI: $0-2=$ natural sediment, $2-5=$ low polluted sediment, $5-10=$ moderately polluted sediment, $10-20=$ highly polluted sediment, and $>20=$ dangerous sediment.

\section{Results and Discussion}

\subsection{Analysis of Metals in Sediments}

The mean concentration of heavy metals ( $\mathrm{Ti}, \mathrm{V}, \mathrm{Cr}, \mathrm{Co}, \mathrm{Ni}$, $\mathrm{Cu}, \mathrm{Zn}, \mathrm{As}, \mathrm{Cd}, \mathrm{Pb}, \mathrm{Rb}, \mathrm{Sr}, \mathrm{Y}, \mathrm{Zr}, \mathrm{Mo}, \mathrm{Ba}, \mathrm{Cs}, \mathrm{U}, \mathrm{Fe}$ and $\mathrm{Mn}$ ) in the sediments are presented in Table 2. The mean concentrations of heavy metals analysed in the sediment samples decreases in the order: $\mathrm{Fe}>\mathrm{Ti}>\mathrm{Zr}>\mathrm{Zn}>\mathrm{Mn}>\mathrm{Pb}>$ $\mathrm{Ba}>\mathrm{Cu}>\mathrm{Cr}>\mathrm{V}>\mathrm{Sr}>\mathrm{Ni}>\mathrm{U}>\mathrm{Y}>\mathrm{Rb}>\mathrm{Co}>\mathrm{As}>\mathrm{Mo}>\mathrm{Cd}>\mathrm{Cs}$; and varied from one station to another (Table 2). The mean concentration of $\mathrm{Ti}, \mathrm{Cr}, \mathrm{Cu}, \mathrm{Zn}, \mathrm{Cd}, \mathrm{Pb}, \mathrm{Y}, \mathrm{Zr}, \mathrm{Mo}$ and $\mathrm{U}$ (12601.08, 151.93, 161.81, 419.30, 2.27, 248.30, 39.69, $3017.50,5.95$ and $49,302 \mu \mathrm{g} / \mathrm{g}$, respectively) greatly exceed the average concentration of these metals in the scale or interval proposed by Turekian and Wedepohl [16], Taylor and McLennan [22] and by Gamo [23] (Table 2). Whereas the 
mean concentration of $\mathrm{V}, \mathrm{Co}, \mathrm{Ni}, \mathrm{As}, \mathrm{Rb}, \mathrm{Sr}, \mathrm{Ba}, \mathrm{Cs}, \mathrm{Mn}$ and Fe $(111.96,9.47,65.43,7.55,12.65,89.50,243.19,0.97$, 313.27 and $39667.32 \mu \mathrm{g} / \mathrm{g}$, respectively) were lower than the average scale value, except for $\mathrm{V}, \mathrm{Ni}$ and As whose mean values were only above the upper continental Crust [22]. The highest mean concentrations of $\mathrm{Ti}, \mathrm{Cd}, \mathrm{Pb}, \mathrm{U}, \mathrm{Y}, \mathrm{Zr}, \mathrm{Mn}$ and Fe $(17877.91,3.77,487.40,72.89,57.76,5015.38,378.57$ and $44747.55 \mu \mathrm{g} / \mathrm{g}$, respectively) were found at station 4 . The lowest mean concentration of all the trace metals except $\mathrm{Cd}$ was observed at station 3 .

Titanium (Ti) is the ninth most abundant element on Earth [24]. Ti content ranges from 8906.54 to $17877.91 \mu \mathrm{g} / \mathrm{g}$, with an average of $12601.08 \mu \mathrm{g} / \mathrm{g}$ (Table 2). The highest concentration was found in site 4 and the lowest in site 3 . The lowest $\mathrm{Ti}$ contents were found in limestones and soils developed on carbonate rich alluvium deposits. Possible sources of $\mathrm{Zn}$ in the stream sediment are motor oil, batteries, grease, phosphate fertilizers, pesticides, swage sludges, asphalt paving, smelting operations and incineration [25]. Zinc is involved in carbohydrate metabolism and in enzymatic systems regulating plant growth. The range of $\mathrm{Zn}$ level in this study was 312.99 to $537.23 \mu \mathrm{g} / \mathrm{g}$, with a mean value of $419 \mu \mathrm{g} / \mathrm{g}$ (Table 2). The highest value was in site 3 and lowest in site 2. The high level in site 3 can have multivariable sources such as brass manufacturing, mining, oil refinery and plumbing.

Chromium (Cr) released by electroplating, steel manufacturing, leather tanning and textile industries is the main source of contamination of water [26]. Cr concentration in sediments ranged from 142.03 to $170.05 \mu \mathrm{g} / \mathrm{g}$ with a mean value of $151.93 \mu \mathrm{g} / \mathrm{g}$ (Table 2). The high concentration of $\mathrm{Cr}$ was found in samples from site 3 located downstream of the soap factory. Cr concentration was also very high in all other sites (1, 2 and 4) (145.34, 150.30, $142.03 \mu \mathrm{g} / \mathrm{g}$, respectively) compared to the average shale value. Chromium enrichment in sediment could be caused by both natural and anthropogenic activities such as tanneries and textile factories [27]. Heavy metals such as lead $(\mathrm{Pb})$, chromium $(\mathrm{Cr})$, cadmium $(\mathrm{Cd})$ and copper $(\mathrm{Cu})$ are widely used during the production of color pigments of textile dyes. Textile dyes pollutants are being released to the environment at various stages of operation therefore it is necessary that the pollutants are treated before discharge using zeolite with and without alum. A study was carried out to compare the effectiveness of treatment using zeolite with and without alum for the removal of heavy metals $(\mathrm{Pb}, \mathrm{Cu}, \mathrm{Cd}, \mathrm{Cr})$ in textile effluent. The concentrations of these heavy metals in the textile waste water samples were reduced to more than 50 percent after treating with zeolite. The sequence in increasing order of removal efficiency of these heavy metals using zeolite was $\mathrm{Cd}<\mathrm{Pb}<\mathrm{Cr}<\mathrm{Cu}[28]$.

The mean concentrations of Copper $(\mathrm{Cu})$ in sediments ranged from 51.97 to $334.20 \mu \mathrm{g} / \mathrm{g}$, with an average value of $161.81 \mu \mathrm{g} / \mathrm{g}$ (Table 2). The results of this study reveal that the concentrations of $\mathrm{Cu}$ decreased in the order from site 2, which showed the highest, down to site 3,4 and 1 . The mean concentration of $\mathrm{Cu}$ in sediments of the Mgoua river was higher than the average shale value. Many researchers were reported that the effluents from the urban areas are the main cause for the elevated levels of trace metals in the aquatic systems [29].

Cadmium $(\mathrm{Cd})$ is highly toxic to most plants and animal species, of which the main anthropogenic sources relate to metallurgical industries, mine wastes, sewage sludge, and municipal effluents [28]. The range of $\mathrm{Cd}$ in sediments of Mgoua river was 1.10 to $3.77 \mu \mathrm{g} / \mathrm{g}$ with an average value of $2.27 \mu \mathrm{g} / \mathrm{g}$. The highest value of $\mathrm{Cd}$ was detected in site 4 $(3.77 \mu \mathrm{g} / \mathrm{g})$ and the least at Site $2(1.10 \mu \mathrm{g} / \mathrm{g})$ (Table 2). Cd results from all the sampling sites were largely exceeding the reference values. Several factors including municipal runoff, atmospheric deposition, and domestic and industrial effluents could be responsible for the high levels of $\mathrm{Cd}$.

Lead $(\mathrm{Pb})$ is considered to be the second metal in the list of 20 most poisonous heavy metals. $(\mathrm{Pb})$ in river and generally come from different sources, including the natural rock composition of surrounding areas and human activities, such as metal plating, fungicides and insecticides, asphalt, phosphate fertilizers, and sewage sludges [30]. $\mathrm{Pb}$ is considered a good indicator of pollution by urban run-off water. The use of leaded gasoline has been mainly responsible for the $\mathrm{Pb}$ pollution load during the 20th century in urban areas [31]. In this study, the concentration of $\mathrm{Pb}$ in surface sediments varied between 102.77 and $487.40 \mu \mathrm{g} / \mathrm{g}$, with a mean value of $248.30 \mu \mathrm{g} / \mathrm{g}$. The highest mean concentration of $\mathrm{Pb}$ was found at sample $4(487.40 \mu \mathrm{g} / \mathrm{g})$, and the lowest at sample $3(102.77 \mu \mathrm{g} / \mathrm{g})$ (Table 2). $\mathrm{Pb}$ concentrations were much higher than the standard values in all sample sites (Table 2). This may be attributed to the presence of many potential sources such as industrial effluents, wastewater from gas production plant and ship breaking yard, sewage outfall from port city, and other local factories. In general, the main sources of these elements are from anthropogenic input, such as contribution of leaded fuel from automobiles and car batteries and extensive use of the antifouling paints by shipping activities [28].

Yttrium ( $\mathrm{Y}$ ) is considered to be non-essential for living organisms. Yttrium is more harmful to the working environment, as it could cause lung embolisms with long-term exposure. Yttrium may also cause cancer, and therefore constitute a threat to the liver when it accumulates in the human body. In this study, the mean concentration of $Y$ in sediments varied from 21.59 to $57.76 \mu \mathrm{g} / \mathrm{g}$, with an average value of $39.69 \mu \mathrm{g} / \mathrm{g}$ (Table 2). Obaje et al. [32] obtained similar results in surface sediments of Gora River in Nigeria.

$\mathrm{Zr}$ is mined from the mineral zircon that is highly resistant to weathering [24]. The content of zirconium in the analyzed sediments ranges from 1030.51 to $5015.38 \mu \mathrm{g} / \mathrm{g}$ with a mean value of $3017.52 \mu \mathrm{g} / \mathrm{g}$ (Table 2). Maximum $\mathrm{Zr}$ concentration was found in sample from site 4 , located downstream with relatively many human activities. The high enrichment of $\mathrm{Zr}$ in sediment may be probably due to intense weathering of the Pan-granitoids, as a major factor for the enrichment.

Molybdenum (Mo) is an essential trace element for the 
health of plant, animal and humans. Moreover it has played an important part in the evolution of on earth [33]. Molybdenum occurs naturally in minerals, rocks and soils as well as in aqueous forms. The mean concentration of Mo in sediment ranged from 4.83 to $6.62 \mu \mathrm{g} / \mathrm{g}$ with an average of $5.95 \mu \mathrm{g} / \mathrm{g}$ (Table 2). The probable source may be strong affinity of this metal to organic matter, oxides of $\mathrm{Fe}, \mathrm{Al}$ and $\mathrm{Mn}$ as well as many clay minerals of these sites. Mo concentration was above the standard value in all studied sites. The high level of Mo could also be related to the varied anthropogenic sources in the area due by the predominance of anthropogenic sources in the sediments.

Various anthropogenic activities involving the processing or use of uranium rich materials may modify the natural abundance of uranium in stream sediments. The content of $U$ ranged from 30.08 to $72.89 \mu \mathrm{g} / \mathrm{g}$, averaging $49.30 \mu \mathrm{g} / \mathrm{g}$ (Table 2). The highest content, $72.89 \mu \mathrm{g} / \mathrm{g}$, was found at Point 4 which is in close proximity to many industries (soap manufacturing, textile, metal works and garages), while the lowest, $30.08 \mu \mathrm{g} / \mathrm{g}$, was measured at Point 2 near the market.
The mean concentration of $U$ in this study was higher than the Geochemical Background value (Table 2). This high concentration of $U$ may be due to the various anthropogenic activities involving the processing or use of uranium rich materials that modify the natural abundance of uranium in sediments. According to Petrescu et al. [34], these activities include various mining operations and the industrial processing for the manufacturing of nuclear fuel and of other products.

The average concentrations values of $\mathrm{V}, \mathrm{Co}, \mathrm{Ni}, \mathrm{As}, \mathrm{Rb}, \mathrm{Sr}$, $\mathrm{Ba}, \mathrm{Cs}, \mathrm{Fe}$ and $\mathrm{Mn}$ were 111.96, 9.47, 65.43, 7.55, 12.65, $89.50,243.19,0.97,39667.32$, and $313.26 \mu \mathrm{g} / \mathrm{g}$, respectively (Table 2). It could be observed from Table 2 that, the mean concentrations of $\mathrm{Co}, \mathrm{Rb}, \mathrm{Sr}, \mathrm{Ba}, \mathrm{Cs}, \mathrm{Fe}$ and $\mathrm{Mn}$ were below the average shale values, as well as the upper continental crust and Japanese river sediment average values. Whereas the average concentration of $\mathrm{V}$ and $\mathrm{Ni}$, are lowest than Geochemical background, and As is above upper continental crust and Japanese river sediment and lower than the average shale values.

Table 2. Heavy metals mean concentrations $(\mu \mathrm{g} / \mathrm{g})$ of the surface sediments of Mgoua River, Douala, Cameroon

\begin{tabular}{|c|c|c|c|c|c|c|c|}
\hline \multirow{2}{*}{ Heavy metals } & \multicolumn{4}{|c|}{ Sampling sites } & \multirow{2}{*}{ Min. } & \multirow{2}{*}{ Max. } & \multirow{2}{*}{ Mean } \\
\hline & Site 1 & Site 2 & Site 3 & Site 4 & & & \\
\hline $\mathrm{Ti}$ & 13960.15 & 9659.7 & 8906.54 & 17877.91 & 8906.54 & 17877.91 & 12601.08 \\
\hline V & 116.08 & 103.1 & 103.64 & 125.00 & 103.1 & 125 & 111.96 \\
\hline $\mathrm{Cr}$ & 145.34 & 150.3 & 170.05 & 142.03 & 142.03 & 170.05 & 151.93 \\
\hline Co & 8.26 & 8.70 & 10.94 & 9.99 & 8.26 & 10.94 & 9.47 \\
\hline $\mathrm{Ni}$ & 52.66 & 68.80 & 86.83 & 53.43 & 52.66 & 86.83 & 65.43 \\
\hline $\mathrm{Cu}$ & 51.97 & 334.2 & 171.42 & 89.66 & 51.97 & 334.2 & 161.81 \\
\hline $\mathrm{Cd}$ & 2.65 & 1.10 & 1.55 & 3.77 & 1.10 & 3.77 & 2.27 \\
\hline $\mathrm{Zn}$ & 385.13 & 537.23 & 312.99 & 441.86 & 312.99 & 537.23 & 419.30 \\
\hline $\mathrm{Pb}$ & 218.56 & 184.46 & 102.77 & 487.40 & 102.77 & 487.40 & 248.30 \\
\hline $\mathrm{U}$ & 56.76 & 30.08 & 37.48 & 72.89 & 30.08 & 72.89 & 49.30 \\
\hline $\mathrm{Rb}$ & 14.04 & 15.70 & 11.04 & 9.83 & 9.83 & 15.70 & 12.65 \\
\hline $\mathrm{Sr}$ & 110.21 & 85.4 & 62.72 & 99.68 & 62.72 & 110.21 & 89.50 \\
\hline $\mathrm{Y}$ & 53.01 & 26.40 & 21.59 & 57.76 & 21.59 & 57.76 & 39.69 \\
\hline $\mathrm{Mn}$ & 338.71 & 252.99 & 282.79 & 378.57 & 252.99 & 378.57 & 313.26 \\
\hline $\mathrm{Fe}$ & 36754.11 & 36127.22 & 41040.42 & 44747.55 & 36127.22 & 44747.55 & 39667.32 \\
\hline Cs & 1.03 & 1.45 & 0.54 & 0.86 & 0.54 & 1.45 & 0.97 \\
\hline $\mathrm{Ba}$ & 315.82 & 329.23 & 136.96 & 190.74 & 136.96 & 329.23 & 243.19 \\
\hline
\end{tabular}

\subsection{Comparative Study of Sediment Samples of Mgoua River with Background}

The available data for a comparative analysis with background and toxicological reference values for river sediments, along with average values obtained for trace metals of representative basin of Mgoua River sediments are summarized in Table 3. It is evident that the average concentration of $\mathrm{Ti}, \mathrm{Cr}, \mathrm{Cu}, \mathrm{Zn}, \mathrm{Cd}, \mathrm{Pb}, \mathrm{Y}, \mathrm{Zr}$, Mo and $\mathrm{U}$ in the sediments of the basin of Mgoua River exceeded the geochemical background (shale standard and continental crust), and the Japanese river sediment average, except Co, $\mathrm{Rb}, \mathrm{Sr}, \mathrm{Ba}, \mathrm{Cs}, \mathrm{Fe}$ and $\mathrm{Mn}$, were lower than the respective average shale value and Japanese average river sediment data (Table 3). The high concentration values of metal in the river basin may be attributed to multiple sources especially anthropogenic inputs from the catchment area, which transport composite waste effluents from various industrial and residential areas. In this study, the average value of $\mathrm{V}, \mathrm{Ni}$ and As exceeded some standard values (upper continental crust value and Japanese average river sediment value) except the mean shale value. The result reveals that the levels of trace metals found in the sediments of Mgoua River might cause adverse effects on the aquatic ecosystems.

\subsection{Anthropogenic Contribution of Heavy Metals}

Many indices were used to determine the degree of heavy metal pollution in surface sediments of the Mgoua river in Cameroon. The level of contamination from heavy metals was evaluated by determining the Geoaccumulation Index $\left(\mathrm{I}_{\mathrm{geo}}\right)$, 
Contamination factor (CF), Pollution load index (PLI), Enrichment Factor (EF) and pollution sedimentary index (IPS). In the explanation of the geochemical data, the choice of background values plays a critical role. Many researchers have used the average shale values or the average crustal abundance data as reference baselines [35].
Geoaccumulation Index $\left(I_{\text {geo }}\right)$

According to the Muller [15] formula, the calculated results of $I_{\text {geo }}$ values of the sediments are given in Table 4 and varied from one metal to the other as well as from place to place.

Table 3. Mean concentrations of the trace element $(\mu \mathrm{g} / \mathrm{g})$ in sediments, compared to the world average and sediments of other world rivers.

\begin{tabular}{|c|c|c|c|c|}
\hline \multirow{2}{*}{ Heavy metals } & \multirow{2}{*}{ Mean $^{a}$} & \multicolumn{2}{|c|}{ Geochemical Background } & \multirow{2}{*}{ Japanese river sediment ${ }^{d}$} \\
\hline & & Average shale value $^{\mathrm{b}}$ & Upper continental crust ${ }^{\mathrm{c}}$ & \\
\hline $\mathrm{Ti}$ & 12601.08 & 4600 & 3000 & \\
\hline V & 111.96 & 130 & 107 & 131 \\
\hline $\mathrm{Cr}$ & 151.93 & 90 & 85 & 65.2 \\
\hline $\mathrm{Co}$ & 9.47 & 19 & 17 & \\
\hline $\mathrm{Ni}$ & 65.43 & 68 & 44 & 25.1 \\
\hline $\mathrm{Cu}$ & 161.81 & 45 & 25 & 30.6 \\
\hline $\mathrm{Zn}$ & 419.30 & 95 & 71 & 118 \\
\hline As & 7.55 & 13 & 1.5 & 9.32 \\
\hline $\mathrm{Cd}$ & 2.27 & 0.3 & 0.098 & 0.158 \\
\hline $\mathrm{Pb}$ & 248.30 & 20 & 17 & 23.1 \\
\hline $\mathrm{Rb}$ & 12.65 & 140 & 112 & 69.7 \\
\hline $\mathrm{Sr}$ & 89.50 & 300 & 350 & 153 \\
\hline $\mathrm{Y}$ & 39.69 & 26 & 22 & 18.1 \\
\hline $\mathrm{Zr}$ & 3017.50 & 160 & 190 & 56.2 \\
\hline Mo & 5.95 & 2.6 & 1.5 & 1.28 \\
\hline $\mathrm{Ba}$ & 243.19 & 580 & 550 & 408 \\
\hline Cs & 0.97 & 4.6 & 4.6 & 3.95 \\
\hline $\mathrm{U}$ & 49.30 & 3.7 & 2.8 & \\
\hline $\mathrm{Fe}$ & 39667.32 & 47200 & 56300 & 61300 \\
\hline $\mathrm{Mn}$ & 313.26 & 850 & 950 & 1260 \\
\hline
\end{tabular}

${ }^{a}$ This study

${ }^{\mathrm{b}}$ Turekian and Wedepohl (1961)

${ }^{\mathrm{C}}$ Taylor and McLennan (1995)

${ }^{\mathrm{d}}$ Gamo (2007).

Table 4. Geo-accumulation index (Igeo) of the studied metals in sediments of the studied area.

\begin{tabular}{|c|c|c|c|c|c|}
\hline \multirow{2}{*}{ Heavy Metal } & \multicolumn{4}{|c|}{ Sampling Sites } & \multirow{2}{*}{ Mean } \\
\hline & Igeo_site 1 & Igeo_site 2 & Igeo_site 3 & Igeo_site 4 & \\
\hline $\mathrm{Ti}$ & 1.02 & 0.49 & 0.37 & 1.37 & 0.81 \\
\hline V & -0.75 & -0.92 & -0.91 & -0.64 & -0.81 \\
\hline $\mathrm{Cr}$ & 0.11 & 0.15 & 0.33 & 0.07 & 0.17 \\
\hline $\mathrm{Co}$ & -1.79 & -1.71 & -1.38 & -1.51 & -1.60 \\
\hline $\mathrm{Ni}$ & -0.95 & -0.57 & -0.23 & -0.93 & -0.67 \\
\hline $\mathrm{Cu}$ & -0.38 & 2.31 & 1.34 & 0.41 & 0.92 \\
\hline $\mathrm{Cd}$ & 2.56 & 1.29 & 1.78 & 3.07 & 2.17 \\
\hline $\mathrm{Zn}$ & 1.43 & 1.91 & 1.14 & 1.63 & 1.53 \\
\hline $\mathrm{Pb}$ & 2.86 & 2.62 & 1.78 & 4.02 & 2.82 \\
\hline $\mathrm{U}$ & 3.35 & 2.44 & 2.76 & 3.72 & 3.07 \\
\hline $\mathrm{Rb}$ & -3.90 & -3.74 & -4.25 & -4.42 & -4.08 \\
\hline $\mathrm{Sr}$ & -2.03 & -2.40 & -2.84 & -2.17 & -2.36 \\
\hline $\mathrm{Y}$ & 0.44 & -0.56 & -0.85 & 0.57 & -0.10 \\
\hline $\mathrm{Mn}$ & -1.91 & -2.33 & -2.17 & -1.75 & -2.04 \\
\hline $\mathrm{Fe}$ & -0.95 & -0.97 & -0.79 & -0.66 & -0.84 \\
\hline Cs & -2.74 & -2.25 & -3.68 & -3.00 & -2.92 \\
\hline $\mathrm{Ba}$ & -1.46 & -1.40 & -2.67 & -2.19 & -1.93 \\
\hline
\end{tabular}

According to Muller [17] Scale, a qualitative scale of pollution intensity, $I_{\text {geo }}$ values for majority of the elements $(\mathrm{V}$, $\mathrm{Co}, \mathrm{Ni}, \mathrm{As}, \mathrm{Rb}, \mathrm{Sr}, \mathrm{Mn}, \mathrm{Fe}, \mathrm{Cs}$ and $\mathrm{Ba}$ ) at all sites had negative (Table 4), indicating minimal influence of anthropogenic contamination in the sediments, except site 1 for $\mathrm{Cu}$ and sites
(2 and 3) for Y. Such a result suggests an unpolluted sediment status in the Mgoua river, as previously reported by Rosha et al. [36]. Metals such as $\mathrm{Cr}$ and Mo were from unpolluted to moderately polluted $\left(0<\mathrm{I}_{\text {geo }}<1\right)$ exhibited class 1 in all sampling sites, but for Ti in sites 2 and 3, $\mathrm{Cu}$ in site 4 and $\mathrm{Y}$ in 
sites 1 and 4 . The $\mathrm{I}_{\text {geo }}$ values for $\mathrm{Zn}$ in all sampling locations exhibited class 2 , indicating a moderately polluted sediment quality $\left(1<\mathrm{I}_{\text {geo }}<2\right.$, Ti at the level of stations 1 and $4, \mathrm{Cu}$ and $\mathrm{Pb}$ in site 3 and $\mathrm{Cd}$ on sites ( 2 and 3 ). It is evident from Table 4 that according to $I_{\text {geo }}$ class 3 , few of the sampling sites of Mgoua river exhibit moderate to strong contamination $\left(2<\mathrm{I}_{\text {geo }}\right.$ $<3$ ) by $\mathrm{Cu}$ in site $2, \mathrm{~Pb}$ in sites 1 and $2, \mathrm{Cd}$ and $\mathrm{Zr}$ at site 1 and $\mathrm{U}$ in sampling sites 2 and 3. The $\mathrm{I}_{\text {geo }}$ values for $\mathrm{Cd}$ and $\mathrm{Zr}$ in sampling sites 4 and 3 respectively, and $U$ in sites 1 and 4 were heavily contaminated $\left(3<\mathrm{I}_{\text {geo }}<4\right)$ class 4 with exception of all metals in site 2 , but for $\mathrm{Pb}$ in site 4 and $\mathrm{Zr}$ in stations 1 and 4 were heavily to extremely contaminated as exhibited in class 5. On the basis of the mean values of $I_{\text {geo }}$, sediments were enriched with metals in the following decreasing order: $\mathrm{Zr}, \mathrm{U}$, $\mathrm{Pb}, \mathrm{Cd}, \mathrm{Zn}, \mathrm{Cu}, \mathrm{Ti}, \mathrm{Mo}, \mathrm{Cr}, \mathrm{Y}, \mathrm{Ni}, \mathrm{V}, \mathrm{Fe}, \mathrm{As}, \mathrm{Co}, \mathrm{Ba}, \mathrm{Mn}, \mathrm{Sr}$, $\mathrm{Cs}$ and $\mathrm{Rb}$.

Contamination factor (CF) and Pollution load index (PLI)

In order to evaluate sediment quality the calculated contamination Factor (CF) and pollution load index (PLI) were presented in Table 5. Maximum mean contamination factor was found in site 4 (5.49). CF>6 (indicates very high contamination) was found in all sampling sites for $\mathrm{U}$ and $\mathrm{Zr}$, $\mathrm{Cd}$ in sites 1 (8.83) and 4 (12.57) and for $\mathrm{Pb}$ in sites 1 (10.93), 2 (9.22) and 4 (24.37). The contamination factor that indicates considerable contamination $(3 \leq \mathrm{CF}<6)$ was obtained in stations 1 and 4 for Ti (3.03, 3.89, respectively), $\mathrm{Zn}$ for all sites, $\mathrm{Cd}$ in sites 2 (3.67) and 5 (5.17) and $\mathrm{Cu}(3.81)$ in station 3. Moderate contaminations $(1 \leq \mathrm{CF}<3)$ were observed for $\mathrm{Cr}$ and Mo in all sampling sites of the study area, for $\mathrm{Cu}$ in sites 1 (1.15) and 2 (1.28), Y in sampling sites 1 (2.04), 2 (1.02) and 4 $(2.22)$, in sites 2 and 3 for Ti $(2.10,1.94)$ and for Ni $(1.01$, 1.28). All sampling sites have Contamination factor $(\mathrm{CF}<1)$ (indicating low contamination) for the heavy metal such $(\mathrm{V}$, $\mathrm{Co}, \mathrm{As}, \mathrm{Rb}, \mathrm{Sr}, \mathrm{Mn}, \mathrm{Fe}, \mathrm{Cs}$ and $\mathrm{Ba}$ ) excepted Ni in sites 2 (1.02) and 3 (1.28). With $\mathrm{CF}<1$, heavy metals as V (0.86), Co (0.50), $\mathrm{Ni}$ (0.96), As (0.58), Rb (0.09), Sr (0.30) Mn (0.37), Fe (0.84), $\mathrm{Cs}(0.21)$ and $\mathrm{Ba}(0.42)$ had low contamination levels and moderate $\mathrm{CF}(1 \leq \mathrm{CF}<3)$ with Ti (2.74), Cr (1.69), Y (1.53) and Mo (2.29). On the basis of the mean values of $\mathrm{CF}$, sediments are enriched for metals ranked in the following order: $\mathrm{Zr}>\mathrm{U}>\mathrm{Pb}>\mathrm{Cd}>\mathrm{Zn}>\mathrm{Cu}>\mathrm{Ti}>\mathrm{Mo}>\mathrm{Cr}>\mathrm{Y}>\mathrm{Ni}>$ $\mathrm{V}>\mathrm{Fe}>\mathrm{As}>\mathrm{Co}>\mathrm{Ba}>\mathrm{Mn}>\mathrm{Sr}>\mathrm{Cs}>\mathrm{Rb}$. On the other hand, the mean values of the contamination factor according to Hakanson's classification (1980) were shown (Table 1), low contamination degree $(\mathrm{CF}<1)$ was observed for metals $\mathrm{V}$ (0.86), Co (0.50), Ni (0.96), As (0.58), Rb (0.09), Sr (0.30), $\mathrm{Mn}(0.37), \mathrm{Fe}(0.84), \mathrm{Cs}(0.21)$ and $\mathrm{Ba}(0.42)$; moderate level $(\mathrm{CF}<3)$ for Ti (2.74), Cr (1.69), Y (1.53) and Mo (2.29); considerable rate $(\mathrm{CF}<6)$ for $\mathrm{Cu}(3.60)$ and $\mathrm{Zn}(4.41)$ and very high contamination $(\mathrm{CF}>6)$ for $\mathrm{Cd}(7.56), \mathrm{Pb}(12.41) \mathrm{U}$ (13.33) and $\mathrm{Zr}$ (18.86). The result of current study was in agreement with Ali et al. (2016) who found that the sediment of Karnaphuli river, Bangladesh was polluted with heavy metals by using CF.

PLI is widely used to evaluate the degree of heavy metal pollution in sediments [37]. The PLI calculated for each site are shown in Table 5. All the studied sites, were found to be polluted (PLI $>1$ ), suggesting inputs from anthropogenic sources. The highest PLI value was found for site 4 (1.56) followed by sites 1 (1.37), 2 (1.29) and 3 (1.17), indicating that these sites are highly polluted. The high level of PLI values observed might be due to the effects of the various industrial and human activities. It is presumed that the occurrence of base metals in river sediments is due to the discharge of industrial effluents, untreated sewage, municipal waste, storm water runoff with road site deposits, and vehicle of the studied area.

Table 5. Contamination Factor (CF) and Pollution Load Index (PLI) of the studied metals in sediments of the studied area.

\begin{tabular}{llllll}
\hline Heavy metals & CF_site 1 & CF_site 2 & CF_site 3 & CF_site 4 & Mean \\
\hline $\mathrm{Ti}$ & 3.03 & 2.10 & 1.94 & 3.89 & 2.74 \\
$\mathrm{~V}$ & 0.89 & 0.79 & 0.80 & 0.96 & 0.86 \\
$\mathrm{Cr}$ & 1.61 & 1.67 & 1.89 & 1.58 & 1.69 \\
$\mathrm{Co}$ & 0.43 & 0.46 & 0.58 & 0.53 & 0.50 \\
$\mathrm{Ni}$ & 0.77 & 1.01 & 1.28 & 0.79 & 0.96 \\
$\mathrm{Cu}$ & 1.15 & 7.43 & 3.81 & 1.99 & 3.60 \\
$\mathrm{As}$ & 0.40 & 0.53 & 0.85 & 0.55 & 0.58 \\
$\mathrm{Cd}$ & 8.83 & 3.67 & 5.17 & 12.57 & 7.56 \\
$\mathrm{Zn}$ & 4.05 & 5.66 & 3.29 & 4.65 & 4.41 \\
$\mathrm{~Pb}$ & 10.93 & 9.22 & 5.14 & 24.37 & 12.41 \\
$\mathrm{U}$ & 15.34 & 8.13 & 10.13 & 19.70 & 13.33 \\
$\mathrm{Rb}$ & 0.10 & 0.11 & 0.08 & 0.07 & 0.09 \\
$\mathrm{Sr}$ & 0.37 & 0.28 & 0.21 & 0.33 & 0.30 \\
$\mathrm{Y}$ & 2.04 & 1.02 & 0.83 & 2.22 & 1.53 \\
$\mathrm{Zr}$ & 24.01 & 6.44 & 13.64 & 31.35 & 18.86 \\
$\mathrm{Mo}$ & 1.86 & 2.35 & 2.55 & 2.40 & 2.29 \\
$\mathrm{Mn}$ & 0.40 & 0.30 & 0.33 & 0.45 & 0.37 \\
$\mathrm{Fe}$ & 0.78 & 0.77 & 0.87 & 0.95 & 0.84 \\
$\mathrm{Cs}$ & 0.22 & 0.32 & 0.12 & 0.19 & 0.21 \\
$\mathrm{Ba}$ & 0.54 & 0.57 & 0.24 & 0.33 & 0.42 \\
$\mathrm{Mean}$ & 3.89 & 2.64 & 2.69 & 5.49 & 3.68 \\
$\mathrm{PLI}$ & 1.37 & 1.29 & 1.17 & 1.56 & 1.35 \\
\hline
\end{tabular}

Enrichment Factor (EF) and Sediment Pollution Index (SPI)

According to Sakan et al. [19] EF values between 0 and 1 indicate that the metal is entirely free from crustal materials or Natural processes, whereas EF values higher than 1 suggest that the sources are more likely to be anthropogenic (Table 6). In this study, the mean EF values of the sediments of Mgoua river varied from natural to anthropogenic (0.11 to 22.00) (Table 6). The sequence of EF of each heavy metal was $\mathrm{Zr}>\mathrm{U}>\mathrm{Pb}>\mathrm{Cd}>\mathrm{Zn}>\mathrm{Cu}>\mathrm{Ti}>\mathrm{Mo}>\mathrm{Cr}>\mathrm{Y}>\mathrm{Ni}>\mathrm{V}>\mathrm{Fe}>\mathrm{As}>$ $\mathrm{Co}>\mathrm{Ba}>\mathrm{Mn}>\mathrm{Sr}>\mathrm{Cs}>\mathrm{Rb}$. Stations 4 is from strongly to extremely polluted by $\mathrm{Zr}$ and $\mathrm{Pb}$, whereas station 1 is strongly to extremely polluted by $\mathrm{Zr}$ only $(24<\mathrm{EF}<48)$. Strongly polluted $(12<\mathrm{EF}<24)$ in sites $(1$ and 2$)$ by $\mathrm{Pb}$, sites ( 1 and 3 ) by $\mathrm{U}$ and $\mathrm{Zr}$, and in station 4 by $\mathrm{Cd}$ and $\mathrm{U}$. Cd in station $1, \mathrm{Cu}$, $\mathrm{Zn}, \mathrm{U}$ and $\mathrm{Zr}$ in sampling site 2 and $\mathrm{U}$ in station 3 represent moderately to strongly polluted $(6<\mathrm{EF}<12)$. High $\mathrm{EF}$ indicates anthropogenic input (industrial wastes, urbanization, domestic wastewater, agricultural ...). The EF for Ti in Sites 1 and 4, $\mathrm{Zn}$ in sites 1, 3 and 4, $\mathrm{Cd}$ and Mo in sites 2 and $\mathrm{Cu}, \mathrm{Cd}$, $\mathrm{Pb}$ in site 3 show EF moderately polluted $(3<\mathrm{EF}<6)$. For $\mathrm{Cr}$, $\mathrm{Y}$ and Mo enrichment in site 1 , in site 2 for $\mathrm{Ti}$ and $\mathrm{Cr}$, for $\mathrm{Ti}$, $\mathrm{Cr}$ and $\mathrm{Mo}$ in site 3 and $\mathrm{Cr}, \mathrm{Cu} \mathrm{Y}$ and $\mathrm{Mo}$ in site 4 are unpolluted to moderately polluted. The last group of elements 
$\mathrm{V}, \mathrm{Co}, \mathrm{Ni}, \mathrm{As}, \mathrm{Rb}, \mathrm{Sr}, \mathrm{Mn}, \mathrm{Fe}, \mathrm{Cs}, \mathrm{Ba}$ in all the sites except $\mathrm{Cu}$ in sites (2, 3 and 4) and $\mathrm{Y}$ in sites (1 and 4) without enrichment $(\mathrm{EF}<1.5)$ indicated also natural sources for the metals (Table 6). The mean EF values for all metals studies except $\mathrm{V}, \mathrm{Co}, \mathrm{Ni}$, As, $\mathrm{Rb}, \mathrm{Sr}, \mathrm{Mn}, \mathrm{Cs}$ and $\mathrm{Ba}$ were $>1.5$ in the sediments of the Mgoua river, suggesting an anthropogenic source.

The highest sediment pollution index IPS), the highest is registered at site 4 (13.24) and the lowest at the site 1 (11.21) (Table 6). On the basis of classification of Singh et al. [21], sites 1 (11.21) and 4 (13.24) indicated highly polluted (10< IPS $<20$ ).

Whereas, sites 2 (4.92) and 3 (5.88) showed low $(2<$ IPS $<$ $5)$ and moderately polluted $(5<$ IPS $<10)$, respectively. However, the level of contamination of the different sites can be classified by ascending pollution order as follows: site $2<$ site $3<$ site $1<$ site 4 . The high level of IPS (11.21 and 13.24) of sites 1 and 4, respectively shows the discharge of untreated industrial waste.

Table 6. Enrichment factors (EF) and Sediment pollution index (IPS) for heavy metals in Mgoua river.

\begin{tabular}{llllll}
\hline Heavy Metals & EF_site 1 & EF_site 2 & EF_site 3 & EF_site 4 & Mean \\
\hline $\mathrm{Ti}$ & 3.90 & 2.74 & 2.23 & 4.10 & 3.24 \\
$\mathrm{~V}$ & 1.15 & 1.04 & 0.92 & 1.01 & 1.03 \\
$\mathrm{Cr}$ & 2.07 & 2.18 & 2.17 & 1.66 & 2.02 \\
$\mathrm{Co}$ & 0.56 & 0.60 & 0.66 & 0.55 & 0.59 \\
$\mathrm{Ni}$ & 0.99 & 1.32 & 1.47 & 0.83 & 1.15 \\
$\mathrm{Cu}$ & 1.48 & 9.70 & 4.38 & 2.10 & 4.42 \\
$\mathrm{As}$ & 0.51 & 0.69 & 0.97 & 0.58 & 0.69 \\
$\mathrm{Cd}$ & 11.34 & 4.79 & 5.94 & 13.26 & 8.83 \\
$\mathrm{Zn}$ & 5.21 & 7.39 & 3.79 & 4.91 & 5.32 \\
$\mathrm{~Pb}$ & 14.03 & 12.05 & 5.91 & 25.71 & 14.42 \\
$\mathrm{U}$ & 19.70 & 10.62 & 11.65 & 20.78 & 15.69 \\
$\mathrm{Rb}$ & 0.13 & 0.15 & 0.09 & 0.07 & 0.11 \\
$\mathrm{Sr}$ & 0.47 & 0.37 & 0.24 & 0.35 & 0.36 \\
$\mathrm{Y}$ & 2.62 & 1.33 & 0.96 & 2.34 & 1.81 \\
$\mathrm{Zr}$ & 30.84 & 8.41 & 15.68 & 33.06 & 22.00 \\
$\mathrm{Mo}$ & 2.39 & 3.07 & 2.93 & 2.53 & 2.73 \\
$\mathrm{Mn}$ & 0.51 & 0.39 & 0.38 & 0.47 & 0.44 \\
$\mathrm{Cs}$ & 0.29 & 0.41 & 0.14 & 0.20 & 0.26 \\
$\mathrm{Ba}$ & 0.70 & 0.74 & 0.27 & 0.35 & 0.51 \\
$\mathrm{Mean}$ & 4.99 & 3.45 & 3.09 & 5.79 & \\
$\mathrm{IPS}$ & 11.21 & 4.92 & 5.88 & 13.24 & \\
\hline
\end{tabular}

\section{Conclusion}

Heavy metal pollution is a major problem in the Mgoua River basin. Douala. In the present study concentrations of $\mathrm{Ti}$, $\mathrm{Cr}, \mathrm{Cu}, \mathrm{Zn}, \mathrm{Cd}, \mathrm{Pb}, \mathrm{Y}, \mathrm{Zr}$, Mo and U, were higher than the safe values which indicated that the river Mgoua is polluted by studied heavy metals and might create an adverse effect on this riverine ecosystem. The geoaccumulation index $\left(\mathrm{I}_{\mathrm{geo}}\right)$, the contamination factor (CF), the pollution load index (PLI), the Enrichment Factor (EF) and the Sediment Pollution Index (SPI) showed that sediments were unpolluted to extremely polluted by heavy metals. This study suggested that point sources of heavy metals in the sediments should be continuously monitored. Industrial effluent and domestic sewage should undergo treatment before disposal to the environment.

\section{Acknowledgements}

The authors of this manuscript are thankful to the Chairperson and all stall of the Laboratoire Geosciences Environnement Toulouse (GET, France) for their availability and the provision of everything necessary to facilitate the analyses. The authors extend their sincere gratitude to editors and reviewers of this manuscript and their proposals and comments important to improving the quality of this paper.

\section{References}

[1] Grigoratos T, Samara C, Voutsa D, Manoli E, Kouras A (2014). Chemical composition and mass closure of ambient coarse particles at traffic and urban background sites in Thessaloniki. Greece. Environmental Sciences and Pollution Research 21: 7708-7722.

[2] Barakat A, Baghdadi ME, Rais J, Nadem S (2012). Assessment of heavy metal in surface sediments of Day river at Beni-Mellal Region, Morocco. Research Journal Environmental Earth Sciences 4: 797-806.

[3] Pejman A, Bidhendi GH, Ardestani M, Saeedi M, Baghvand A (2015). A new index for assessing heavy metals contamination in sediments: A case study. Ecological Indicators 58: 365-373.

[4] Ndjama J (2014). Pollution des systèmes hydrologiques en zones urbaines et impacts environnementaux: Cas du bassin versant de la Mgoua à Douala, Cameroun. Thèse de Doctorat Ph.D. Université de Yaoundé I, Faculté des Sciences, Département des Sciences de la Terre, 224p.

[5] Eneke GT, Kuitcha D, Ako AA, Mafany GT, Takoundjou Fouepe A, Ndjama J, Ntchancho R, Ateba BH, Chanchasekharam D, Ayonghe SN (2015). Acidification of shallow groundwater in the unconfined sandy aquifer of the city of Douala, Cameroon, Western Africa: Implications for groundwater quality and use. Journal of Environmental Earth Sciences. DOI: 10.1007/S12665-015-4681-3.

[6] Fantong WY, Kamtchueng BT, Ketchemen-Tandia B, Kuitcha D, Ndjama J, Fouepe AT, Takem GE, Issa, Wirmvem MJ, Bopda Djomou SL, Ako AA, Nkeng GE, Minoru Kusakabe \& Takeshi Ohba (2016). Variation of hydrogeochemical characteristics of water in surface flows, shallow wells, and boreholes in the coastal city of Douala (Cameroon). ISSN: 0262-6667 (Print) 2150-3435.

[7] Kopa Njueya A, Likeng JDH, Nono A (2012). Hydrodynamique et qualité des eaux souterraines dans le bassin sédimentaire de Douala (Cameroun): cas des aquifères sur formations Quaternaires et Tertiaires. International Journal Biology and Chemistry Sciences 6 (4): 1874-1894.

[8] Ogbeibu AE, Omoigberale MO, Ezenwa MI, Eziza JO, Igwe JO (2014). Using pollution load index and geoaccumulation index for the assessment of heavy metal pollution and sediment quality of the Benin river. Nigeria. Nature Environmental 2: $1-9$.

[9] Bai J, Cui B, Chen B, Zhang K, Deng W, Gao H, Xiao R (2011). Spatial distribution and ecological risk assessment of heavy metals in surface sediments from a typical plateau lake wetland, China. Ecol. Model., 222 (2): 301-306. 
[10] Esmaeilzadeh M, Karbassi A, Moattar F (2016). Assessment of metal pollution in the Anzali Wetland sediments using chemical partitioning method and pollution indices 35 (10): 28-36.

[11] Kerolli-Mustafa, Fajković M, Rončević HS, Ćurković L (2015) Assessment of metals risks from different depths of jarosite tailing waste of Trepça Zinc Industry, Kosovo based on BCR procedure. J. Geochewm. Explor. 148: 161-168.

[12] El-Sammak AA, Abdul-Kassim TA (1999). Metal pollution in the sediments of Alexandria Region. Southern Mediterranean. Egypt. Bull. Environmental Contamination Toxicology 63: 263-270.

[13] Tomlinson DC, Wilson JG, Harris CR, Jeffery DW (1980). Helgolãnder Meeresunters 33: 566-575.

[14] Yaqin J, Yinchang F, Jianhui W, Tan Z, Zhipeng B, Chiqing D (2008). Using geoaccumulation index to study source profiles of soil dust in China. Journal Environmental Sciences 20: 571-578.

[15] Islam MS, Ahmed MK, Raknuzzaman M., Habibullah-Al-Mamun M, Islam MK (2015c). Heavy metal pollution in surface water and sediment: a preliminary assessment of an urban river in a developing country. Ecol. Indic. 48: 282-291.

[16] Turekian KK, Wedepohl KH (1961). Distribution of the elements in some major units of the earth's crust. Bulletin of the Geological Society of American 72: 175-192.

[17] Legorburu I, Rodriguez JG, Borja A, Menchaca I, Solaun O, Valencia V, Galparsoro I and Larreta J (2013). Source characterization and spatio-temporal evolution of the metal pollution in the sediments of the Basque estuaries (Bay of Biscay). Marine Pollut. Bull. 66 (1-2), 25-38.

[18] Abrahim GMS, Parker RJ (2008). Assessment of heavy metal enrichment factors and the degree of contamination in marine sediments from Tamaki Estuary. Auckland. New Zealand. Environmental Monitoring and Assessment 136: 227-238.

[19] Sakan SM, Djordjevic DS, Manojlovic DD, Polic PS (2009). Assessment of heavy metal pollutants accumulation in the Tisza River sediments. Journal Environmental Management 90: 3382-3390.

[20] Malvandi H (2017). Preliminary evaluation of heavy metal contamination in the Zarrin-Gol River sediments. Iran. Marine Pollution Bulletin. MPB-08421; No of Pages 7.

[21] Singh M, Mülle G, Singh IB (2002). Heavy metals in freshly deposited stream sediments of rivers associated with urbanization of the Ganga plain. India. Water Air Soil Pollution 141: 35-54.

[22] Taylor SR, McLennan SM (1995). The geochemical evolution of the continental crust. Reviews of Geophysics 33: 241-265.

[23] Gamo T (2007). Geochemistry of Environment (in Japanese). Baihu-kan. 235 p.

[24] Humsa TZ, Srivastava RK (2015). Impact of rare earth mining and processing on soil and water environment at Chavara.
Kollam. Kerala: a case study. Procedure Earth Planet Sciences 11: $566-581$.

[25] Eker SC, Sipahi F, zkan O, Gumu MK (2017). Evaluation of potentially toxic element contents and $\mathrm{Pb}$ isotopic compositions in Ankara Stream sediments within an urban catchment in central Turkey. Environmental Earth Sciences 76: 647.

[26] Rumpa S, Rumki N, Bidyut S (2011). Sources and toxicity of hexavalent chromium. Journal of Coordination Chemistry. 64 (10): 1782-1806.

[27] Halimoon N, Goh Soo YR (2010). Removal of Heavy Metals from Textile Wastewater using Zeolite. EnvironmentAsia 3: 124-130.

[28] Khan MZH, Hasan MR, Khan M, Aktar S, Fatema K (2017). Distribution of Heavy metals in surface sediments of the Bay of Bengal Coast. Journal of Toxicology, Volume 2017, Article ID 9235764, $7 \mathrm{p}$.

[29] Fu J, Zhao C, Luo Y, Liu C, Kyzas GZ, Luo Y, Zhao D, An S, Zhu H (2014). Heavy metals in surface sediments of the Jialu River. China: their relations to environmental factors.

[30] Srarfi FRR, Bol R, Martina I, Nadhem GB, SlimShimi N (2019). Stream sediments geochemistry and the influence of flood phosphate mud in mining area. Metlaoui. Western south of Tunisia. Environmental Earth Sciences 78: 211-223.

[31] Mukai H, Tanaka A, Fujii T, Nakao M (1994). Lead isotope ratios of airborne particulate matter as tracers of long-range transport of air pollutants around Japan. Journal of Geophysical Research 99 (2): 3717-3726.

[32] Obaje SO, Akpoborie IA, Ugbe FC, Onugba A (2015). Rare Earth and Trace Elements Distribution in Sediments of River Gora. Minna Area. North-Central Nigeria: Implication for Provenance. Earth Sciences Research 4 (1): 103-112.

[33] Smedley PL, Kinniburgh DG (2017). Molybdenum in natural waters: A review of occurrence. Distributions and controls. Applied Geochemistry 84: 387-432.

[34] Petrescu L, Bilal E, Iatan L (2010). The impact of a uranium mining site on the stream sediments (Crucea mine. Romania). Scientific Annals of the School of Geology 100: 121-126.

[35] Islam MS, Ahmed MK, Habibullah-Al-Mamun M, Hoque MF (2015b). Preliminary assessment of heavy metal contamination in surface sediments from a river in Bangladesh. Environmental Earth Sciences 73: 1837-1848.

[36] Rosha R, Bajracharya RM, Subodh S, Chhatra MS, Shichang K, Qianggong Z, Tripathee L, Pengfei C, Dipesh R, Guo J, Bhawani SD (2017). Potentially Toxic Trace Metals in Water and Lake-Bed Sediment of Panchpokhari, an Alpine Lake Series in the Central Himalayan Region of Nepal. Water Air Soil Pollution 228: 303.

[37] Bhuiyan MAH, Dampare SB, Islam MA, Suzuki S (2015). Source apportionment and pollution evaluation of heavy metals in water and sediments of Buriganga river. Bangladesh. using multivariate analysis and pollution evaluation indices. Environmental Monitoring and Assessment 187: 4075-4075. 